\title{
Análise da estrutura e organização esportiva da natação no Estado de São Paulo
}

CDD. 20.ed. 796.06

797.2

http://dx.doi.org/10.1590/1807-55092015000400583
Tatiana de Barros MEIRA*

Flávia da Cunha BASTOS* Maria Tereza Silveira BÖHME*
*Escola de Educação Física e Esporte, Universidade de São Paulo.

\section{Resumo}

0 objetivo deste artigo é analisar a estrutura de organização para o desenvolvimento da natação de alto rendimento no Estado de São Paulo. Para isso foi realizada uma entrevista semiestruturada com 11 técnicos de natação de alto rendimento do Estado de São Paulo, e dois funcionários da Federação Aquática Paulista. Na análise dos dados foi utilizado o método do Discurso do Sujeito Coletivo. Verificou-se que os clubes e as Entidades Municipais de Práticas Desportivas são responsáveis tanto pela formação esportiva, quanto pelo treinamento a longo prazo para a natação de alto rendimento. A administração das ações e políticas esportivas para o desenvolvimento da natação no Estado de São Paulo não acontece de modo centralizado, não segue orientação de entidades nacionais como o COB ou o Ministério do Esporte, ou de alguma entidade de administração da modalidade, como CBDA ou FAP. A elaboração e administração de ações e políticas esportivas para o desenvolvimento da natação de alto rendimento ocorre nos clubes e Entidades Municipais de Práticas Desportivas, de maneira autônoma e individualizada. Deste modo, cada entidade de prática é responsável pela definição de suas diretrizes, aplicação de recursos financeiros, prestação de contas, auditorias e relacionamento com patrocinadores.

PalaVRAS-Chave: Estrutura esportiva; Natação; Desenvolvimento do esporte de alto rendimento.

\section{Introdução}

Para a estruturação de um programa esportivo de um país, há a necessidade da atuação de organizaçóes que desenvolvam processos de planejamento, implantação, operacionalização e controle. A estrutura geral do esporte de alto rendimento em diversos países acontece nos níveis municipal, estadual, federal e internacional. Nos níveis municipal e estadual, a organização ocorre por meio dos clubes ou entidades de prática desportiva, que são afiliadas a entidades de administração do esporte, como as ligas, as associações e as federações; já nos níveis nacional e internacional, a organização ocorre por meio de centros de treinamento e seleçóes nacionais, controlados por confederaçôes, comitês olímpicos e federaçóes internacionais ${ }^{1}$. Em diversos países, a estrutura organizacional voltada à implantação e controle das modalidades esportivas é definida por programas desenvolvidos pelo governo ou por entidades governamentais que visam a desenvolver o esporte como um todo, nas suas três formas de manifestação: educacional, participativo e de rendimento ${ }^{2}$.

No Brasil, assim como em países como Alemanha, Austrália, Japão e Reino Unido, o Governo /Entidades Governamentais/ Instituições Nacionais de Esporte são responsáveis por controlar o esporte de al to rendimento nacionalmente. Esses órgãos nacionais são responsáveis por elaborar linhas e diretrizes para instituiçôes subordinadas e parceiras (Ministérios, Comitês Olímpicos, Confederações, Federações, Ligas, Secretarias Estaduais e Municipais, etc. $)^{3}$.

Dada a relevância do tema, na última década foram publicados trabalhos de pesquisa que analisaram a estrutura organizacional de programas nacionais de esporte, por meio de diferentes formas de investigaçáo, mas focados em compreender o funcionamento de programas esportivos em diferentes países e principalmente naqueles com destaque em competições internacionais ${ }^{2,4-10}$. 
Esses trabalhos demonstram que é possível compreender os diferentes aspectos que envolvem os sistemas esportivos de vários países, além de identificar particularidades de acordo com cada país e observar açóes semelhantes entre eles, indicando a existência de pontos comuns relevantes no desenvolvimento do esporte de alto rendimento que devem ser destacados e valorizados ${ }^{11}$.

Para a análise de sistemas esportivos, são considerados os fatores que podem influenciar o sucesso esportivo internacional em três níveis: macro, meso e micro. O macronível compreende as condiçōes gerais (sociais, econômicas, históricas, culturais entre outras); o mesonível engloba as políticas da sociedade e do respectivo governo voltadas para o esporte; já o micronível é constituído pelos aspectos específicos do treinamento físico e desempenho individual de atletas ${ }^{12}$.

$\mathrm{O}$ sucesso do esporte de alto rendimento internacional é amplamente determinado pelos macrofatores, aproximadamente $50 \%$ do sucesso esportivo internacional é influenciado pelo macronível, pois este nível tem influência direta nos outros níveis. No entanto, cada vez mais a importância deste nível tenderá a diminuir e a importância do mesonível a aumentar, pois muitos países estáo investindo na estruturação de programas esportivos de qualidade. Dessa forma, é possível realizar a comparação de diferentes estruturas esportivas nacionais, com o foco da análise a partir de informaçóes sobre o mesonível ${ }^{4,11}$.

A estruturaçáo esportiva de um país compreende programas de planos e açóes nacionais, sejam esses gerenciados pelo governo, por entidades de prática desportiva, ligas nacionais ou institutos nacionais de esporte, que são elaborados de maneira central, e aplicados em todo o território nacional ${ }^{4,7-8,13}$.

Uma análise sobre a organização, as estruturas e as políticas para o esporte de alto rendimento brasileiro segundo o modelo SPLISS ("Sports Policies Leading to Sport Success") foi realizada no Brasil, e, verificou-se que o país possui açóes voltadas para o desenvolvimento do esporte de alto rendimento oriundas do Comitê Olímpico Brasileiro (COB) e do Ministério do Esporte, as quais são isoladas, algumas delas semelhantes, mas, sem diretrizes centrais norteadoras para as mesmas. De acordo com esse estudo, o esporte brasileiro necessita de estruturação esportiva desenvolvida nacionalmente, para que programas e projetos esportivos funcionem regionalmente de maneira integrada com diretrizes propostas e coordenadas por órgãos governamentais e entidades nacionais do esporte ${ }^{1}$.

Apesar de o Brasil não possuir diretrizes nacionais centralizadas para o esporte de alto rendimento, o país possui bons resultados internacionais em algumas modalidades esportivas nos Jogos Olímpicos, Jogos Pan-americanos e Campeonatos Mundiais.

Neste trabalho, analisamos, de maneira particular, a modalidade de nataçáo no contexto estrutural e organizacional do esporte. De acordo com o desempenho da natação do Brasil nos últimos Jogos Olímpicos (2012/2008/2004/2000/1996/1992) e Jogos Pan-americanos (2010/2007/2003/1999/1995), verifica-se que o desempenho dos nadadores brasileiros de natação merece atenção entre as demais modalidades esportivas no âmbito nacional. Os atletas da natação conquistaram, nesse período, 13 medalhas olímpicas e 145 medalhas em Jogos Pan-americanos ${ }^{14}$. Além disso, foram conquistadas 37 medalhas em campeonatos mundiais (de piscina curta e longa $)^{14-15}$. Com relaçáo aos campeonatos nacionais, verificou-se que entre os 38 melhores clubes ranqueados no ano de 2010, nas 15 primeiras posiçóes, sete deles pertenciam ao Estado de Sáo Paulo ${ }^{16}$.

Visto que a Natação apresentou, nos últimos anos, resultados internacionais em Jogos Olímpicos e campeonatos mundiais, um estudo comparativo buscou entender o contexto de desenvolvimento de nadadores brasileiros medalhistas que treinavam no Brasil e nos Estados Unidos. O autor concluiu que o apoio da família, do treinador especialista, e a prática deliberada foram os fatores necessários para o desenvolvimento dos "experts" da modalidade em ambos os países. No entanto, as diferenças encontradas entre os atletas que treinavam nos Estados Unidos e aqueles que treinavam no Brasil referiam-se principalmente à maior utilização de tecnologias no treinamento, apoio financeiro e acesso ao estudo. Segundo o autor, isso se deve ao fato de que o contexto varia de acordo com as realidades de cada país, demonstrando que programas de esporte de alto rendimento de diferentes países (como é o caso Brasil e Estados Unidos) geram diferentes realidades/contextos de treinamento ${ }^{17}$.

Ou seja, fatores relacionados ao mesonível (políticas voltadas para o esporte) influenciam no micronível (aspectos específicos do treinamento). Portanto, analisar as políticas, açóes e a estrutura esportiva voltadas para a nataçáo de alto rendimento à luz da literatura internacional é importante, pois são examinados fatores que influenciarão o desempenho esportivo no nível de alto rendimento ${ }^{4}$.

Por meio de uma análise dessa natureza é possível identificar lacunas e entender como as entidades responsáveis pela organização e administração da modalidade interagem e se contribuem na elaboração 
de políticas e estratégias para o desenvolvimento da modalidade nos diferentes níveis que ela é desenvolvida.

Dessa maneira, ao passo que a literatura internacional preconiza que devem existir açóes, programas e coordenação nacionais voltados para o desenvolvimento do esporte de alto rendimento, estudos demonstram que o Brasil não caminha de acordo com os modelos internacionais. Por outro lado, o país consegue alcançar resultados esportivos interessantes, neste caso, na modalidade natação. Por isso, surge o questionamento de como isso pode acontecer e quais são os pontos concordantes e dissonantes entre a prática e a teoria.

Assim, para descrever como é organizada e estruturada a natação no Brasil, o Estado de São Paulo foi utilizado como parâmetro, já que as equipes do

\section{Método}

Foi realizada uma pesquisa de natureza descritiva, por meio de um delineamento transversal, do tipo "survey", que se destina a estudar o "status" de um fenômeno ${ }^{18}$.

As informaçóes para a discussão dos resultados encontrados foram obtidas por meio de levantamento documental e bibliográfico, a partir da identificação de material disponível em bibliotecas, sites de busca (Pubmed, Medline e Scopus) e revistas especializadas. Os descritores definidos para a busca em sites de busca foram: administração esportiva, organização esportiva, programas de esporte, esporte de alto rendimento, e modelos de esporte, e para refinar a busca de acordo com os objetivos do estudo, todos os descritores foram relacionados ao descritor "natação" nos idiomas português e inglês. Também foram levantadas fontes documentais institucionais e legais em sites de órgãos governamentais (Ministério do Esporte) e de entidades esportivas (Comitê Olímpico Brasileiro, Confederação Brasileira de Clubes, Confederação Brasileira de Desportos Aquáticos, Federação Aquática Paulista).

\section{Amostra}

Foram convidados os técnicos do Estado de São Paulo pertencentes às 20 entidades de prática desportiva (Clubes e Entidades Municipais de Práticas Desportiva) com os melhores resultados competitivos na categoria adulta nos campeonatos estaduais de natação de 2009. Participaram da amostra os técnicos que aceitaram o convite e se disponibilizaram a participar da pesquisa.
Estado mantêm a hegemonia de resultados competitivos significativos no nível nacional.

A investigação sobre a estrutura organizacional da modalidade natação no Estado de São Paulo se justifica ainda devido à escassez de dados teóricos acerca da estrutura organizacional da modalidade. Por meio de um trabalho de pesquisa desta natureza, é possível obter um panorama geral sobre a organização atual das entidades de prática desportiva para possíveis propostas de melhoria da natação brasileira. Portanto, o objetivo do presente artigo é analisar a estrutura de organizaçáo para o desenvolvimento da natação de alto rendimento no Estado de São Paulo, seguindo parâmetros e modelos estabelecidos pela literatura internacional.

A amostra contou com 11 técnicos; destes, seis técnicos de entidades que representam clubes privados e cinco técnicos de Entidades Municipais de Práticas Desportiva do Estado de São Paulo (São Bernardo do Campo, Santo André, São Caetano do Sul, São José dos Campos e São Paulo). Das entidades que participaram da pesquisa, $81,8 \%$ possuem turmas de treinamento de todas as categorias competitivas de natação. Das 11 entidades participantes, sete fazem parte do "Ranking" Brasileiro de Natação de 2010 que avaliou 38 entidades de prática desportiva da modalidade no Brasil ${ }^{19}$.

Também participaram da amostra dois funcionários do corpo administrativo da Federação Aquática Paulista, entidade que organiza a natação no Estado de São Paulo, que representavam o sistema de organização esportiva e ocupavam cargo administrativo.

Os participantes da pesquisa foram contatados por meio telefônico e/ou eletrônico para o agendamento das entrevistas.

\section{Procedimentos}

O projeto de pesquisa foi aprovado pelo Comitê de Ética na Pesquisa da Escola de Educação Física e Esporte da Universidade de São Paulo sob o número de protocolo de pesquisa 2010/12.

Todos os participantes da pesquisa assinaram o Termo de Consentimento Esclarecido, sendo assegurado seu anonimato.

A fim de descrever a estrutura organizacional da modalidade natação no Estado de São Paulo para o 
alto rendimento, foi verificada a existência ou não de dois dos pontos relevantes para o desenvolvimento do esporte de alto rendimento no contexto internacional ${ }^{7}$ junto à FAP e aos técnicos das entidades selecionadas do Estado de São Paulo7. Os autores elencaram 10 pontos considerados importantes na estruturação do esporte nacionalmente:

Fator 1 - Entendimento claro sobre o papel das diferentes agências envolvidas e uma comunicação efetiva na rede que mantém o sistema esportivo;

Fator 2 -Simplicidade de administração por meio de açôes esportivas e políticas comuns;

Fator 3 - Sistema efetivo para a identificação estatística e monitoramento do progresso de atletas talentosos e de elite;

Fator 4 - Provimento de serviços na área esportiva para criar uma cultura de excelência na qual todos os membros envolvidos (atletas, treinadores, administradores, cientistas do esporte) possam interagir uns com os outros de maneira formal e informal;

Fator 5 - Programas competitivos bem estruturados com intercâmbio internacional;

Fator 6 - Instalaçóes bem desenvolvidas e específicas, com prioridade de acesso para atletas de elite;

Fator 7 - Foco dos recursos disponíveis em um número relativamente pequeno de modalidades esportivas, com identificação daquelas com chances reais de sucesso em nível mundial;

Fator 8 - Planejamento claro e adequado para as necessidades de cada modalidade esportiva;

Fator 9 - Reconhecimento dos custos da excelência esportiva, com destinação de fundos para infraestrutura e pessoal;

Fator 10 - Suporte para a vida e preparaçáo profissional do atleta após o término da carreira esportiva.

Para este estudo foram realizadas entrevistas semiestruturadas, com referência aos aspectos "Organização do sistema esportivo e Administração das açôes e políticas esportivas", fundamentados nos fatores 1 e 2 "Entendimento claro sobre o papel das diferentes agências envolvidas e uma comunicação efetiva na rede que mantém o sistema esportivo" e "Simplicidade de administração por meio de açôes esportivas e políticas comuns"

O roteiro da entrevista foi composto pelas seguintes questóes:

1- "Qual é o papel dessa entidade no processo de desenvolvimento do esporte de alto rendimento?";
2- "Há interação da sua entidade com outras responsáveis pelo desenvolvimento do esporte de alto rendimento (clubes, ligas, federaçôes, confederaçôes, $C O B$, Ministério)? Como ocorre a comunicação?";

3- "Como são definidas as diretrizes e açôes para o desenvolvimento do esporte de rendimento no pais.?";

4- "Para qual (is) órgão (s) esta instituição deve prestar contas?".

As entrevistas foram realizadas pessoalmente pela pesquisadora, as quais foram gravadas e posteriormente transcritas na íntegra.

\section{Análise dos dados}

Para a análise das respostas obtidas por meio das entrevistas, foi utilizado o método do Discurso do Sujeito Coletivo (DSC) ${ }^{20}$. O método de análise se processa por meio do levantamento das expressôes chave, ideias centrais e elaboraçáo do discurso do sujeito coletivo:

a) Expressóes-chave: são os pedaços ou trechos literais do discurso demarcados pela pesquisadora (sublinhadas) e que revelam a essência do depoimento;

b) Ideias centrais: são a expressão linguística que descreve, de forma sintética, precisa e fidedigna, o sentido de cada um dos discursos analisados que vai dar origem, posteriormente, ao Discurso do Sujeito Coletivo;

c) Discurso do Sujeito Coletivo: é um discurso síntese, redigido na primeira pessoa do singular e composto pelas expressóes-chave que têm a mesma ideia central.

Os resultados serão apresentados por meio de tabelas contendo: caracterização das ideias centrais (ICs), número de ICs, percentual em relação ao número total de ICs, percentual de ICs em relação ao número de técnicos (11) e funcionários (dois), relativas à cada questão. Também serão construídos e explicitados os Discursos do Sujeito Coletivo (DSCs) de técnicos e funcionários para cada Ideia Central (IC).

$\mathrm{Na}$ discussão dos resultados serão utilizados parâmetros e modelos estabelecidos por estudos que compararam estruturas esportivas de diferentes países. Ainda que se trate da análise da natação somente no Estado de Sáo Paulo, esses modelos permitem que sejam analisados pontos importantes no desenvolvimento do esporte de alto rendimento em diferentes níveis e modalidades esportivas. 


\section{Resultados}

Na TABELA 1 são apresentados os resultados referentes ao papel da entidade no processo de desenvolvimento do esporte de alto rendimento.
A seguir serão explicitados os Discursos do Sujeito Coletivo (DSCs) de técnicos e funcionários para cada Ideia Central (IC).

TABELA 1 - Caracterização das ideias centrais (ICs), número de ICs, percentual em relação ao número total de ICs, percentual de ICs em relação ao número de técnicos (11) e funcionários (dois), relativas à questão: “Qual é o papel dessa entidade no processo de desenvolvimento do esporte de alto rendimento?”.

\begin{tabular}{rccc}
\hline Caracterizaçáo das ICs & $\begin{array}{c}\text { Número de } \\
\text { ICs }\end{array}$ & $\begin{array}{c}\text { Percentual em relaçáo } \\
\text { ao número total de ICs }\end{array}$ & $\begin{array}{c}\text { Percentual de ICs } \\
\text { em relaçáo ao número de } \\
\text { técnicos e funcionários }\end{array}$ \\
\hline Técnicos (11) & 10 & $38,4 \%$ & $90,9 \%$ \\
Formação esportiva & 8 & $30,7 \%$ & $72,7 \%$ \\
Representante de Prefeitura & 4 & $15,3 \%$ & $36,3 \%$ \\
Formação do cidadão & 2 & $7,6 \%$ & $18,1 \%$ \\
Atender associados & 2 & $7,6 \%$ & $18,1 \%$ \\
Tuncionários (2) Total de ICs & 26 & $100 \%$ & \\
Organizar eventos & 2 & & $100 \%$ \\
Capacitaçóes técnicas esporádicas & 1 & $66,6 \%$ & $50 \%$ \\
Total de ICs & 3 & $33,3 \%$ & \\
\hline
\end{tabular}

\section{Discursos do sujeito coletivo: técnicos}

DSC1: IC - "Alto rendimento" (S1, S3, S4, S5, S6, S7, S8, S9, S10, S11)

Tem essa questão do alto rendimento, que o principal a gente objetiva ir para campeonato paulista, tentar ganhar medalha, aqui sempre foi o berço de muitos nadadores. A gente busca índice pro brasileiro, a gente visa o mais alto rendimento, a gente trabalha pensando em colocar algum atleta a nível pan-americano, a nível mundial, olímpico. E o objetivo está altamente ligado ao Ciclo Olímpico, o objetivo principal do clube é colocar o maior número de atletas na Olimpíada.

\section{DSC2: IC - "Formação esportiva"}

(S1, S2, S3, S4, S8, S9, S10, S11)

Tem um papel importante como qualquer clube na formação, principalmente nas categorias de base. Então a gente, além da formaçáo do atleta, a gente trabalha a parte técnica e a parte do treinamento numa sequência. Porque o atleta, ele entra aqui na categoria mirim, e ele tem uma sequência até ele chegar no Júnior e Sênior. Então a gente dá prioridade às crianças mais novas. $\mathrm{E}$ o nosso foco é a garotada até 17 anos de idade. Então é realmente fortalecer a base do esporte em São Paulo, então esse é nosso objetivo.

DSC3: IC - "Representante de Prefeitura" (S1, S7, S8, S10)

Então, a Prefeitura tem um investimento financeiro na equipe de Natação, e a gente, em troca, a representa em Jogos Regionais e Jogos Abertos. Porque é bom pra cidade, porque a gente tem uma equipe muito forte pra nadar esse tipo de competição, e é bom pro clube, porque ajuda a gente também a arcar com muitas despesas que a Natação tem. Para a Prefeitura, o importante para eles é Jogos da Juventude, Jogos Regionais e Jogos Abertos, eles não estão nem aí para Paulistas e Brasileiros, então, é por isso que a Prefeitura dá o apoio financeiro às modalidades.

DSC4: IC - "Formação do cidadão" (S1, S4)

A formação como cidadáo, porque nem todos viram atletas, na verdade, lá em cima são poucos, pouquíssimos que vão ser atletas de alto rendimento, 
essa questão também da parte técnica, da parte de progressão que ele tem do clube é muito importante. A gente tem o principal aí, focar o atleta, focar a família, pro esporte, eu não diria de rendimento nesse exato momento, mas, pra formação dele, se no caso vier a ser um atleta de alto rendimento, uma expressão a título nacional, ou internacional, a família já tem uma consciência de qual vai ser o envolvimento de todo mundo nesse processo.

\section{DSC5: IC - “Atender associados" (S3, S11)}

A intenção é atender ao grupo de associados daqui, por meio de uma modalidade competitiva que dê funçóes tanto educativas e sociocomportamentais, quanto competitivas. Dentro do clube é uma das principais modalidades pelo número de atletas sócios que participam. Apesar de não ser um clube altamente competitivo, ele nasceu do social para o esporte.

\section{Discursos do sujeito coletivo: funcionários}

\section{DSC6: IC - “Organizar eventos” (S1, S2)}

A Federação Aquática Paulista é uma entidade ligada à Confederação Brasileira de Desportos
Aquáticos e que, por sua vez, é ligada ao Comitê Olímpico Brasileiro. Na Federação, por estatuto, ela tem como obrigação, organizar os campeonatos para os atletas das entidades filiadas. E a Federação hoje tá focada, principalmente, na realização de eventos aos clubes filiados. Os eventos máximos no Estado, os Campeonatos Estaduais. Na verdade a federação, ela é responsável, no Estado de São Paulo, de organizar os eventos.

DSC7: IC- “Capacitações técnicas esporádicas”(S2)

E também, periodicamente, já aconteceram capacitações aos técnicos dos clubes filiados à Federação, inclusive com a participação de alguns técnicos estrangeiros, ou mesmo do Gustavo Borges, que é uma referência dentro da modalidade, já realizou capacitação para os atletas e para os técnicos filiados à Federação Aquática Paulista.

$\mathrm{Na}$ TABELA 2, são apresentados os resultados referentes à interação entre as entidades responsáveis pelo desenvolvimento do esporte de alto rendimento. A seguir são explicitados os Discursos do Sujeito Coletivo (DSCs) de técnicos e funcionários para cada Ideia Central (IC).

TABELA 2 - Caracterização das ideias centrais (ICs), número de ICs, percentual em relação ao número total de ICs, percentual de ICs em relação ao número de técnicos (11) e funcionários (dois) relativas à questão: "Há interação da sua entidade com outras responsáveis pelo desenvolvimento do esporte de alto rendimento (clubes, ligas, federações, confederações, COB, Ministério)? Como ocorrea comunicação?”.

\begin{tabular}{|c|c|c|c|}
\hline Caracterização das ICs & $\begin{array}{l}\text { Número de } \\
\text { ICs }\end{array}$ & $\begin{array}{l}\text { Percentual em relaçáo } \\
\text { ao número total de ICs }\end{array}$ & $\begin{array}{l}\text { Percentual de ICs } \\
\text { em relaçáo ao número de } \\
\text { técnicos e funcionários }\end{array}$ \\
\hline \multicolumn{4}{|l|}{ Técnicos (11) } \\
\hline Filiação à FAP para competições & 10 & $40 \%$ & $90,9 \%$ \\
\hline $\begin{array}{r}\text { Não tem interação com COB e } \\
\text { CBDA }\end{array}$ & 6 & $24 \%$ & $54,5 \%$ \\
\hline Outros clubes informalmente & 6 & $24 \%$ & $54,5 \%$ \\
\hline Suporte para atletas da seleção & 3 & $12 \%$ & $27,2 \%$ \\
\hline Total de ICs & 25 & $100 \%$ & \\
\hline \multicolumn{4}{|l|}{ Funcionários (2) } \\
\hline CBDA & 2 & $40 \%$ & $100 \%$ \\
\hline $\begin{array}{r}\text { Clubes, associaçóes, prefeituras, } \\
\text { academias e colégios }\end{array}$ & 2 & $40 \%$ & $100 \%$ \\
\hline Ministério para bolsa-atleta & 1 & $20 \%$ & $50 \%$ \\
\hline Total de ICs & 5 & $100 \%$ & \\
\hline
\end{tabular}




\section{Discursos do sujeito coletivo: técnicos}

DSC1: IC - "Filiação à FAP para competições" (S1, S2, S3, S4, S5, S6, S7, S8, S10, S11)

Então, primeiro seria a nossa Região, da nossa região vai para a Federação Paulista, da Federação Paulista vai para a Confederação Brasileira de Desportos Aquáticos. Pra gente poder participar de qualquer evento competitivo na modalidade Natação, a gente tem que estar filiado ou vinculado á Federação Aquática paulista, que é o órgão que rege a Natação no Estado de São Paulo. Ele é filiado à Federação Aquática Paulista, à FAP, e a FAP tá filiada à Confederação Brasileira de Desportos Aquáticos. Essa relação é pura e simplesmente a gente estar filiado para poder participar das competiçôes. Eles geralmente organizam os eventos, organizam a parte burocrática de inscrição das competições, e só isso. A comunicação é somente referente à competição, não tem nada, nenhum trabalho de formação, nenhum trabalho de reciclagem, nada, nada, nada.

DSC2: IC - "Não tem interação com COB e CBDA" (S1, S2, S6, S8, S9, S10)

Infelizmente, essa integração, essa interação não existe muito, não. Isso é um "problemaço" do Brasil, não há interação. $\mathrm{Na}$ verdade, é assim, não tem apoio nenhum das Federaçôes, do $\mathrm{COB}$ ou da CBDA. O Clube é e por isso que tem a grande dificuldade, cada clube tem que arcar com as suas despesas, mas não existe nenhum vínculo com o clube, assim como não existe nenhum vínculo entre a Confederação Brasileira de Desportos Aquáticos e o clube.

DSC3: IC - "Outros clubes informalmente" (S1, S3, S5, S7, S9, S10)

Nós temos uma boa relação com a maioria dos outros lugares, a gente faz muitos treinos em conjunto, o pessoal vem treinar aqui, a gente vai treinar em outras entidades. Então, existe um bom relacionamento, sim, com outras entidades. A gente faz com as categorias mais de base, que a gente chama, que são aquelas crianças de 9, 10, 11,12 , até 13 anos. A gente faz uma interação bem grande, onde convida, faz amistosos, fazemos competiçôes de nível não federado. Normalmente, quando tem os Torneios Regionais, os outros times vêm pra cá, porque aqui é um lugar bom pra se nadar. E normalmente quando a gente necessita, a gente vai para outros clubes.

DSC4: IC - "Suporte para atletas da seleção" (S4, S6, S9)

A única coisa que a Confederação faz é, a partir do momento que o atleta tá pronto, tá num nível internacional, aí ela acaba entrando nas seleções e tendo suas viagens e seus campeonatos custeados pela Confederação. Esses atletas também acabam recebendo um salário do patrocínio da CBDA, que é os Correios. É assim: primeiro você tem que chegar com um atleta com nível de olimpíada, pra depois eles olharem para você. Mas, o patrocínio dos Correios é um patrocínio que ninguém sabe, não tem critério, a Confederação direciona esse patrocínio para os atletas que eles querem.

\section{Discursos do sujeito coletivo: funcionários}

\section{DSC5: IC - "CBDA" (S1, S2)}

\begin{abstract}
Acima da gente tem a CBDA; nos reportamos somente a eles. A gente não entra em contato com o $\mathrm{COB}$, nem o Ministério, só com a CBDA. A gente segue a hierarquia. A gente fala só com a CBDA, é o CBDA que fica responsável por falar como Ministério, com o COB. Eles têm essa responsabilidade.
\end{abstract}

DSC6: IC - "Clubes, associações, prefeituras, academias e colégios" $(\mathrm{S} 1, \mathrm{~S} 2)$
Para baixo existem clubes privados, associações, prefeituras. Quem pode é filiado a associações e clubes, que são entidades sem fins lucrativos. Eles têm que ser obrigatoriamente filiados. A comuni- cação com os clubes é via email, telefone, ou eles vêm até aqui na federação. A Federação trabalha com os clubes filiados, então, os principais clubes do Estado de São Paulo, e consequentemente do Brasil, estão filiados à Federação, e existe uma co- municação bem intensa para o desenvolvimento do esporte. E há os vinculados, que são academias e colégios, que são entidades que têm em seus contratos com fins lucrativos, possuem contrato social. Então, quem tem estatuto sem fins lucra- tivos, obrigatoriamente tem que ser filiado, e daí esses filiados têm direito a ter atletas federados. 
DSC7: IC - "Ministério para bolsa-atleta" (S2)

Então, nossa interação com o Ministério do Esporte se limita à emissão de atestados aos atletas que pediram o bolsa-atleta.
Na TABELA 3, são apresentados os resultados referentes às diretrizes e açóes para o desenvolvimento do esporte de alto rendimento. A seguir, serão explicitados os Discursos do Sujeito Coletivo (DSCs) de técnicos e funcionários para cada Ideia Central (IC).

TABELA 3 - Caracterização das ideias centrais (ICs), número de ICs, percentual em relação ao número total de ICs, percentual de ICs em relação ao número de técnicos (11) e funcionários (dois) relativas à questão: "Como são definidas as diretrizes eações para o desenvolvimento do esportederendimento no país?".

\begin{tabular}{|c|c|c|c|}
\hline Caracterizaçâo das ICs & $\begin{array}{l}\text { Número } \\
\text { de ICs }\end{array}$ & $\begin{array}{l}\text { Percentual em relaçáo } \\
\text { ao número total de ICs }\end{array}$ & $\begin{array}{l}\text { Percentual de ICs } \\
\text { em relaçáo ao número de } \\
\text { técnicos e funcionários }\end{array}$ \\
\hline \multicolumn{4}{|l|}{ Técnicos (11) } \\
\hline Não existe diretriz nacional & 7 & $36,8 \%$ & $63,6 \%$ \\
\hline Cada clube trabalha da sua forma & 5 & $26,3 \%$ & $45,4 \%$ \\
\hline Só para atletas da seleção & 3 & $15,7 \%$ & $27,2 \%$ \\
\hline CBDA por meio do Conselho Técnico & 3 & $15,7 \%$ & $27,2 \%$ \\
\hline Bolsa-atleta & 1 & $5,2 \%$ & $9 \%$ \\
\hline Total de ICs & 19 & $100 \%$ & \\
\hline \multicolumn{4}{|l|}{ Funcionários $(2)$} \\
\hline Conselho Técnico Regional/Nacional & 2 & $100 \%$ & $100 \%$ \\
\hline Total de ICs & 2 & $100 \%$ & $100 \%$ \\
\hline
\end{tabular}

\section{Discursos do sujeito coletivo: técnicos}

DSC1: IC - "Não existe diretriz nacional" (S1, S2, S4, S6, S8, S9, S11)

Eu acho que não existe. Eu acho que não tem nenhuma política pública para desenvolver o esporte no Brasil. Não existe uma coisa homogênea, ou, que segue um padrão determinado pela Confederação ou pela Federação. Cada clube tema a sua metodologia própria de desenvolvimento. Não vejo nenhum envolvimento do poder público em relação ao meu esporte e aos outros também.

DSC2: IC - "Cada clube trabalha da sua forma" $\left(\mathrm{S}_{3}, \mathrm{~S} 4, \mathrm{~S} 6, \mathrm{~S} 9, \mathrm{~S} 11\right)$

No Brasil, cada clube trabalha da sua melhor forma, cada entidade trabalha de um jeito e não tem um plano de ação unificado. Cada clube tem sua forma de desenvolver os atletas, não existe uma coisa homogênea, ou, que segue um padrão determinado pela Confederação ou pela Federação. Cada clube tem a sua metodologia própria de desenvolvimento e de detecção de talentos. Hoje, o que faz a Natação acontecer no Brasil são os clubes.

DSC3: IC - “Só para atletas da seleção” (S7, S8, S10)

Olha, eu sei que tem algumas coisas, mas, é em relação sempre ao alto rendimento. A Confederação, ela tem uma política onde ela auxilia alguns nadadores, ela investe nesses nadadores para participar de campeonatos fora do país, ajuda financeiramente. As diretrizes são muito mais para levar alguns atletas, vamos dizer, assim, os mais talentosos dentro da Natação nacional, para alguns eventos mais importantes. A Confederação Brasileira tá com o esporte muito concentrado; ela tem os 40 atletas patrocinados pelos Correios que podem tudo. Muitas vezes, a CBDA expõe o plano, o plano para o próximo ciclo olímpico, a gente vê e acha legal, mas, quem faz parte disso mesmo são uns cinco ou seis clubes maiores. 
DSC4: IC - "CBDA por meio do Conselho Técnico" $\left(\mathrm{S}_{3}, \mathrm{~S}_{5}, \mathrm{~S} 6\right)$

Os eventos, eles são montados pelos Conselhos Técnicos da Confederação Brasileira de Desportos Aquáticos, pelo Conselho Técnico Estadual de cada Estado. O Conselho Técnico Nacional tá tentando fazer um calendário compatível ao calendário americano e europeu. Então, as diretrizes de treinamento, as diretrizes de desenvolvimento, quem rege hoje são os técnicos dos principais clubes que dão as ideias, porque existe uma comissão permanente. Então, o presidente da Confederação, o supervisor técnico, eles acompanham, eles sempre estão nas reuniōes para garantir que tudo aconteça, mas eles apresentam, e quem decide são os principais técnicos.

\section{DSC5: IC - "Bolsa-atleta” (S1)}

Você tem, por exemplo, o bolsa-atleta, que é um apoio que o Governo dá pra alguns atletas, mas, são pouquíssimos atletas que têm esse apoio; é um apoio financeiro. Alguns atletas aqui já tiveram bolsa-atleta, hoje, não têm mais. E você tem alguns critérios pra esse, pra bolsa-atleta, pra você se inscrever, mas, ninguém sabe como é o esquema, os critérios de escolha.

\section{Discurso dosujeito coletivo: funcionários}

DSC6: IC- "Conselho Técnico Regional/Nacional” $(\mathrm{S} 1, \mathrm{~S} 2)$

É o conselho técnico que define o rumo da Natação paulista. Monta o calendário, elabora o regulamento, estabelece os índices de participação, tudo. A federação não faz nada sem consultar o conselho técnico. Então, tudo é o conselho técnico que define. Três vezes por ano, nós nos reunimos com esse Conselho Técnico, que traz aí quais são os anseios dos técnicos dentro de todo o Estado de São Paulo. Então, seja para a formação de novos regulamentos, de novas diretrizes, de novas orientaçoes, a gente sempre procura estar consultando o Conselho técnico, isso é uma prerrogativa da Presidência.

Na TABELA 4 são apresentados os resultados referentes à prestação de contas das entidades no desenvolvimento do esporte de alto rendimento. A seguir, são explicitados os Discursos do Sujeito Coletivo (DSCs) de técnicos e funcionários para cada Ideia Central (IC).

TABELA 4 - Caracterização das ideias centrais (ICs), número de ICs, percentual em relação ao número total de ICs, percentual de ICs em relação ao número de técnicos (11) e funcionários (dois) relativas à questão: "Para qual (is) órgão (s) esta instituição deve prestar contas?".

\begin{tabular}{|c|c|c|c|}
\hline Caracterização das ICs & $\begin{array}{l}\text { Número de } \\
\text { ICs }\end{array}$ & $\begin{array}{l}\text { Percentual em relaçáo } \\
\text { ao número total de ICs }\end{array}$ & $\begin{array}{l}\text { Percentual de ICs } \\
\text { em relaçáo ao número de } \\
\text { técnicos e funcionários }\end{array}$ \\
\hline \multicolumn{4}{|l|}{ Técnicos (11) } \\
\hline Para a Prefeitura & 5 & $31,2 \%$ & $45,4 \%$ \\
\hline Para o próprio clube & 5 & $31,2 \%$ & $45,4 \%$ \\
\hline Não presta contas à CBDA e à FAP & 4 & $25 \%$ & $36,3 \%$ \\
\hline Várias auditorias & 1 & $6,2 \%$ & $9 \%$ \\
\hline Para patrocinadores & 1 & $6,2 \%$ & $9 \%$ \\
\hline Total de ICs & 16 & $100 \%$ & \\
\hline \multicolumn{4}{|l|}{ Funcionários (2) } \\
\hline Para os clubes filiados & 2 & $100 \%$ & $100 \%$ \\
\hline Total de ICs & 2 & $100 \%$ & \\
\hline
\end{tabular}

\section{Discursos do sujeito coletivo: técnicos}

DSC1: IC - "Para a Prefeitura” (S1, S2, S7, S8, S10)

A nossa equipe, é uma equipe da Prefeitura, então, a gente presta contas à Prefeitura.
Existe o Departamento de Esportes, então, a gente presta contas ao Departamento de Esportes, e consequentemente à Prefeitura. Só a Prefeitura mesmo, que é um patrocínio. Meu clube presta conta pra Prefeitura que subsidia a Natação. 
DSC2: IC - "Para o próprio clube"

(S1, S3, S4, S6, S11)

A nível competitivo, a gente só presta contas mesmo sobre o próprio clube. Porque nosso dinheiro, a nossa verba, vem diretamente do clube. O clube é uma entidade particular, e ele tem uma verba destinada aos esportes competitivos, então, nós temos que prestar contas ao clube. E o clube presta contas para os associados do clube; nossa prestação de contas é muito mais com o associado no clube, com os atletas, do que com alguma entidade vinculada.

DSC3: IC - "Não presta contas a CBDA e FAP" $\left(\mathrm{S}_{3}, \mathrm{~S}_{4}, \mathrm{~S}_{5}, \mathrm{~S} 6\right)$

Para ninguém. O clube hoje é uma instituição privada, então, ela não tem que prestar contas pra ninguém. Então, isso também é uma coisa extremamente preocupante, porque se existem trabalhos que estão sendo mal desenvolvidos, não existe gerência de ninguém. $\mathrm{O}$ clube não é obrigado a prestar contas, ou, a definir o desenvolvimento que ele está fazendo para a Federação, pra Confederação. A Federação e a Confederação, elas não sabem absolutamente nada o que acontece nos clubes.
DSC4: IC - "Para várias auditorias" (S9)

Ah, são muitas auditorias, muitas ISOS, porque o clube é muito grande. Só de piscina semiolímpica semiaquecida são 43 no Estado. Então é assim, eles prestam contas pro Tribunal de Contas da União, a Controladoria-Geral, tudo. Então, eles prestam contas à " $n$ " auditorias, eu não sei nem te dizer.

\section{DSC5: IC - "Para patrocinadores" (S6)}

Hoje, a Natação é patrocinada por um patrocinador e pega uma ajuda da Lei de Incentivo ao Esporte. Então, realmente, a esses aí eles devem prestar contas, aos patrocinadores, pois eles estão colocando um dinheiro no clube para ele conseguir se desenvolver.

\section{Discurso do sujeito coletivo: funcionários}

DSC6: IC - "Para os clubes filiados" (S1, S2)

Para os clubes filiados, só para os clubes. Tem a ordinária anual, que é para prestar contas pros clubes. Na verdade, a Federação presta contas para os filiados; nós trabalhamos para os clubes que são filiados à Federação Aquática Paulista.

\section{Discussão}

Os estudos sobre a estrutura organizacional esportiva demonstram a importância de um país possuir um sistema nacional de esporte, já que a sistematização da estrutura organizacional de diferentes países reflete-se em bons resultados esportivos internacionais ${ }^{2,47,21-23}$.

A descrição do sistema esportivo da natação no Estado de Sáo Paulo é apresentada por meio dos resultados apresentados nas TABELAS 1 e 2, além dos DSCs de técnicos e funcionários, referentes ao papel e a interação entre as entidades envolvidas.

Como verificado, $90 \%$ afirmam que o papel de sua entidade no desenvolvimento do esporte de alto rendimento é o "Alto rendimento", e 72\%, a "Formação esportiva". Ou seja, essas entidades de prática desportiva pesquisadas realizam o trabalho de desenvolvimento esportivo, desde a base até o alto rendimento, por meio de categorias de base/ formaçáo e categorias adultas/alto rendimento.

Também foi possível verificar que entidades de prática desportiva com diferentes objetivos participam da estrutura competitiva da natação em Sáo Paulo, já que a amostra possui entidades de prática desportiva do setor privado e do setor público. Nesse sentido, foram observadas ICs e DSCs destoantes: se por um lado 36\% dos técnicos citam como papel da entidade "Representantes de Prefeitura", outros 18\% citam "Atender associados".

Os resultados indicam que as entidades de prática desportiva pesquisadas têm, entre seus objetivos, a funçáo de desenvolver o esporte de base e alto rendimento, sejam essas entidades de prática desportiva, clubes privados ou representantes de projetos pontuais de Entidades Municipais de Práticas Desportiva. Cada entidade, isoladamente, é responsável pelo desenvolvimento de atletas de natação em São Paulo e, consequentemente, no Brasil.

No nível nacional, a Confederação Brasileira de Desportos Aquática (CBDA) é a Confederação Esportiva responsável pelas modalidades: Nataçáo, Polo Aquático, Nado Sincronizado, Maratonas Aquáticas 
e Saltos Ornamentais ${ }^{16}$. Já no Estado de São Paulo, a Federação Aquática Paulista (FAP) possui as mesmas características da CBDA, mas de maneira regional. A FAP atua no Estado de São Paulo por meio de oito Delegacias que auxiliam na organização da Federação em cidades do interior e litoral ${ }^{18}$.

Mas em nível local, as entidades desportivas atuam independentemente. Na realidade brasileira, as Entidades Municipais e Estaduais de Práticas Desportiva possuem autonomia para elaborar e administrar programas e projetos próprios. De acordo com a Lei n. 9.615, de 1998, “os Estados e o Distrito Federal constituem seus próprios sistemas, respeitadas as normas estabelecidas nesta Lei e a observância do processo eleitoral; aos Municípios é facultado constituir sistemas próprios de desporto, observado o disposto nesta Lei e, no que couber, na legislação do respectivo Estado" ${ }^{24}$.

Assim, ainda que no Brasil, o Ministério do Esporte seja responsável, por meio da Secretaria Nacional de Esporte de Alto Rendimento, por desenvolver o esporte de alto rendimento nacionalmente, por meio da implementação, supervisão e gerenciamento de programas e projetos governamentais, e a que a CBDA e a FAP sejam reposnsáveis pelo desenvolvimento da modalidade natação nacional e regionalmente, verifica-se na prática que as entidades que trabalham com o esporte de alto rendimento atuam de forma descentralizada, com programas e projetos próprios.

Diferentemente, em países como a China o Governo, de forma centralizadora, controla o esporte nacionalmente e é responsável por formular e administrar políticas para o esporte que são implementadas nacionalmente, nos níveis das cidades e das províncias. Essa centralização de ações e decisões é característica de países do antigo bloco comunista. Mas, também, é um ponto adotado por países ocidentais como forma de organizar o esporte nacionalmente. Ou seja, países com contextos históricos, sociais e culturais diferentes conseguem estabelecer estratégias semelhantes para estruturar o esporte nacionalmente $\mathrm{e}^{7-8}$.

Além disso, verificou-se, também, o papel do clube privado na realidade brasileira, que consiste em desenvolver o esporte de base e de alto rendimento. Existiam no Brasil, em 2010, 13.826 clubes, que atendiam a mais de 55 milhóes de associados. Dada a importância dos clubes brasileiros na formação esportiva e no esporte de alto rendimento, em 16/03/2011, a Presidente da República. Dilma Roussef, sancionou o texto com a edição da Lei 12.345/11, que alterou a Lei 9.615/98 (Nova Lei Pelé), que seria posteriormente regulamentada, a partir disso $0,5 \%$ da verba da Loteria Federal, a qual deve ser repassada aos clubes filiados ${ }^{25-26}$.

Uma observação importante a ser feita referente aos clubes no Brasil, é a dificuladde de filiação, que muitas vezes fica restrita à elite econômica do país. Os sócios desses clubes, por vezes, colocam restrições à utilização da estrutura dos clubes por terceiros. Como resultado, o acesso às escolas de esporte, em geral, estão restritas aos sócios. Além disso, não existe no país uma rede interligada do sistema esportivo, entre clubes e escolas ${ }^{27}$.

Esse fato tem um peso importante no desenvolvimento da natação de alto rendimento no país, já que é uma modalidade que necessita de instalaçóes específicas para a sua prática. No Estado de São Paulo em 2011, sob responsabilidade do Governo do Estado, existiam uma piscina semiolímpica e uma piscina olímpica que fazem parte de Conjuntos Desportivos do Estado ${ }^{27-28}$. E, sob responsabilidade da Prefeitura de São Paulo, eram 15 piscinas semiolímpicas e duas piscinas olímpicas. Esses dados demonstram a insuficiência de instalações públicas voltadas para a prática da natação na capital do Estado, restringindo a prática a um número limitado de crianças e jovens que têm acesso a um clube privado, ou academias particulares de natação ${ }^{29}$. Não foram encontrados dados sobre o número e disponibilidade de piscinas públicas e de clubes privados no Estado de São Paulo, assim como nas redes de ensino pública e particular.

Já em países como Austrália, Japão e Alemanha, o esporte é desenvolvido em escolas e clubes esportivos. No entanto, quando o atleta chega a um nível competitivo de destaque, ainda que seja nas categorias mais novas, é encaminhado para centros especializados das diferentes modalidades, controlados pelo Governo ou entidades nacionais do esporte. Nesses centros, é desenvolvido o treinamento para o esporte de alto rendimento ${ }^{2,8,30}$.

Outras respostas observadas foram de alguns técnicos (18\%), que citam a experiência pessoal com o atleta como maneira de "Formação do cidadão" e consideram que a maioria dos atletas que participa do processo de formação esportiva e treinamento para o alto rendimento náo se tornará atleta de alto rendimento. Dessa forma, a entidade também possui o papel de preparar essas crianças e jovens para a vida, além da possibilidade da participação no esporte de alto rendimento.

$\mathrm{E}$, segundo os funcionários da FAP, esta tem por função: "Organizar eventos", o que atende a um dos objetivos da entidade FAP:

(...) (b) regulamentar e dirigir os campeonatos estaduais, torneios, competições e festivais 
desportivos em todo o território sob a sua jurisdição"; $(. . .)^{17}$.

A FAP, assim como outras Federações e Confederaçôes Esportivas, tem, em seus estatutos, a função de implementar sua modalidade por meio de diferentes estratégias e objetivos. Na prática, no entanto, essas entidades privilegiam a organização e participação em eventos/campeonatos da modalidade. Este fato é ilustrado pelo documento "Demonstração da Aplicação dos Recursos Provenientes da Lei Agnelo Piva 2009", disponibilizado pelo COB. Nesse documento, são publicados os resumos da aplicação dos recursos financeiros recebidos pelas Confederaçóes de Modalidades Olímpicas do COB, provenientes da Lei Piva. A CBDA utilizou em 2008 e 2009, respectivamente, $59,9 \%$ e $48,1 \%$ de seus recursos na organização e participação em competiçóes ${ }^{31}$.

Assim fica claro que, no nível nacional, grande parte dos recursos financeiros é destinada aos eventos esportivos, o que se repete no nível estadual, por meio da Federação Aquática Paulista.

$\mathrm{Na}$ Austrália, a organização da natação fica sob responsabilidade da Australian Swimming Incorporated (ASI). Essa entidade passou por uma remodelação nos anos 80 que permitiu a esse país chegar aos mais altos níveis de resultados competitivos na natação mundial. Os autores afirmam que a entidade possui quatro áreas-chave, nas quais se investem grandes quantias: a) desenvolvimento de instalaçóes esportivas; b) manutençáo de atletas de elite, para que náo necessitem ter outro emprego; c) investimento na capacitaçáo técnica, apoio da ciência e medicina esportiva; d) oportunidades de competiçóes de alto rendimento ${ }^{32}$.

Em termos gerais, com relação ao papel das entidades no desenvolvimento do esporte de alto rendimento, verificou-se que, no Estado de São Paulo, os clubes e as Entidades Municipais de Práticas Desportivas são os responsáveis pelo desenvolvimento dos atletas de natação, desde a formação até o alto nível, ao passo que a FAP é responsável, prioritariamente, pela organização de campeonatos e eventos.

Entender o papel de cada entidade ligada ao esporte de alto rendimento é importante, mas, mais importante ainda é verificar a comunicação/interação entre as entidades, pois isso permite aferir se essa estrutura é eficiente ${ }^{4,7}$. Nesse sentido, verificou-se que a IC mais presente entre os técnicos foi "Filiação à FAP para competições” (90\%). Além disso, os técnicos destacam que a comunicação com essas entidades é unicamente relacionada à participação em competiçôes e aspectos burocráticos de filiação entre as entidades.
Os técnicos também destacam que não existe interação entre suas entidades de prática desportiva com o COB e a CBDA (54\%), ou seja, ainda que os clubes possuam interação com a FAP, nem todos possuem interação com órgãos nacionais como COB e CBDA.

Observou-se que existe uma linha de comunicação vertical ascendente na interação entre as entidades: os clubes se comunicam com a FAP, que se comunica, por sua vez, com a CBDA, e esta é responsável pela comunicação com o COB. Essa estrutura organizacional assemelha-se à organização do esporte na Alemanha. $\mathrm{Na}$ Alemanha, a base do sistema são os clubes, que se comunicam diretamente com a Federação Esportiva Municipal, esta com a Federação Esportiva Regional, esta com as Confederaçóes Esportivas, as quais se comunicam, por sua vez, com o Comitê Olímpico Nacional e a Federação Alemã de Esportes ${ }^{2}$.

No entanto, a Federação Alemã de Esportes representa o Governo e mantém uma comunicação firme e próxima com as Federaçôes Municipais e Regionais, na intenção de desenvolver o esporte nacionalmente. Este aspecto diferencia as estruturas entre os dois países, pois, como observado, na realidade da natação no Estado de São Paulo, cada clube ou Entidade Municipal de Práticas Desportiva trabalha com autonomia e náo existe essa forma de interação com outras entidades.

Outro fato interessante apontado pelos técnicos, "Suporte para atletas da seleção" (27\%), levanta discussão. De acordo com os técnicos, quando o atleta apresenta resultados competitivos internacionais importantes, existe o contato por parte da CBDA diretamente com esse atleta para patrocínio. Cabe ressaltar a forma diferenciada de comunicação entre CBDA e atleta, que foge à estrutura, pois exclui o clube e a Federação.

Além da Bolsa-atleta concedida pelo Ministério do Esporte, foi instituída em 2009, pelo Governo do Estado de São Paulo, a Bolsa Talento Esportivo (Lei n. 13.556, de 9 de junho de 2009). A Bolsa Talento Esportivo, assim como a Bolsa-atleta federal, visa a incentivar o desporto por meio da concessão de apoio financeiro aos atletas dos vários níveis de excelência, praticantes de modalidades olímpicas e paraolímpicas $^{28}$. No entanto, nenhum dos técnicos asseverou receber esse tipo de apoio por parte do Governo do Estado de São Paulo.

Na estrutura organizacional da natação, de acordo com 54\% dos técnicos, existe a comunicação entre os clubes. Esse fator é positivo, pois possibilita aos clubes realizar eventos competitivos em diferentes categorias 
e treinos em conjunto. Os países que possuem sistemas de competiçóes de diferentes categorias e níveis competitivos têm possibilidade de preparar de maneira mais eficiente seus atletas para competiçóes internacionais. Além disso, para clubes particulares, qualquer forma de competição é importante para manter a existência deles ${ }^{5,32}$.

De acordo com funcionários da FAP, confirma-se a estrutura citada anteriormente, já que a entidade possui interação vertical ascendente com a CBDA e o Ministério do Esporte, e, de modo descendente com clubes, associaçôes, Prefeituras, academias e colégios.

$\mathrm{O}$ tipo de interação entre a FAP e a CBDA não foi especificado, mas, segundo os funcionários da FAP, o processo ocorre de maneira hierárquica. A comunicação com o Ministério do Esporte ocorre somente para a emissão de documentos da entidade para o atleta que solicita a Bolsa-atleta. Dentre os documentos que o atleta deve apresentar para a obtenção desta, consta uma declaração da Federação Esportiva responsável, confirmando a filiação do atleta a essa entidade ${ }^{33}$.

Ainda de acordo com os funcionários entrevistados, os clubes, as associaçóes e as Prefeituras são filiados para a participação em eventos competitivos com atletas federados. Em 2011, a FAP possuía 160 entidades de prática desportiva filiadas e vinculadas, o que equivalia a aproximadamente seis mil atletas no Estado de São Paulo. Nesse sentido, a entidade conta com oito Delegacias Regionais e um Conselho Técnico para administrar todas as instituiçōes e atletas filiados à entidade ${ }^{18}$.

De maneira geral, verificou-se que, no sistema esportivo voltado para o desenvolvimento da natação de alto rendimento no Estado de São Paulo, existe interação e comunicação entre os clubes e as Entidades Municipais de Práticas Desportiva com a FAP. Essa comunicação ocorre de maneira limitada aos aspectos burocráticos e na participação em eventos e competições organizados pela Federação. A CBDA se comunica diretamente com os atletas para distribuição de patrocínio, e os atletas diretamente com o Ministério do Esporte para a obtenção da Bolsa-atleta.

Assim, a partir da discussão acima, é possível descrever o sistema esportivo voltado para o desenvolvimento da natação de alto rendimento no Estado de São Paulo.

Na FIGURA 1, é apresentado o sistema esportivo, assim como o papel de cada entidade no desenvolvimento da natação no Estado de São Paulo, de acordo com os técnicos e os funcionários entrevistados.

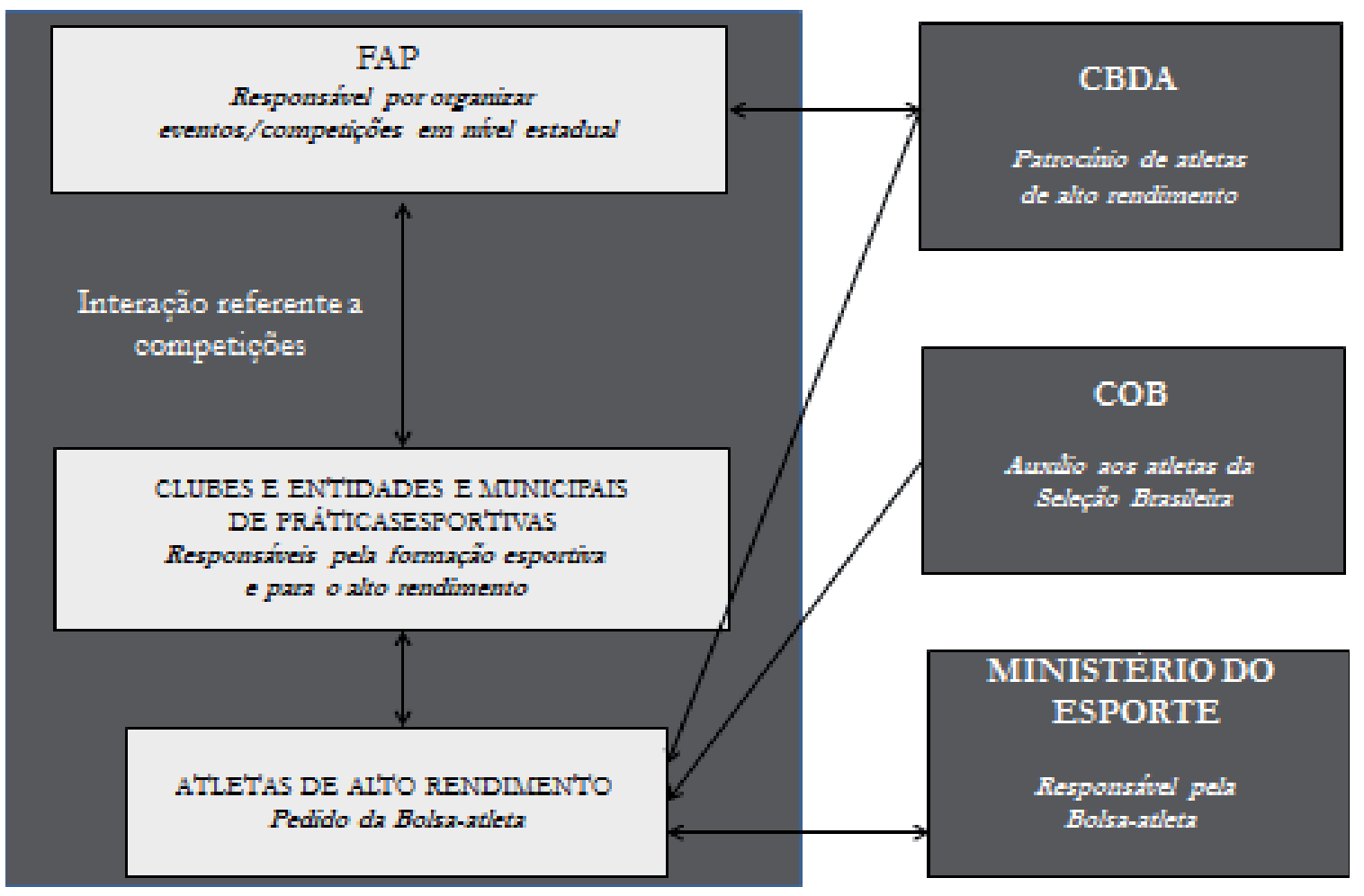

FIGURA 1 - Organograma sobre o sistema esportivo voltado para a natação de alto rendimento: papel e interação entre as entidades. 
Em relação à organização da estrutura esportiva de um país, é necessário que o Governo e/ou as Instituiçóes Nacionais de Esporte possuam açóes centralizadoras que possam ser administradas e implantadas nacionalmente, para que o país possa alcançar sucesso esportivo internacional. A coordenação nacional de ações possibilita a maximização do suporte em nível regional para Confederaçôes, Federaçôes, atletas e técnicos ${ }^{4,7}$.

Nesse sentido, 63\% dos técnicos entrevistados afirmaram que não existe uma diretriz nacional para o desenvolvimento da natação de alto rendimento no país e $45 \%$ deles afirmam que cada clube trabalha da sua própria forma. Segundo os mesmos, não existe uma política pública por parte do Governo, assim como não existe nenhuma ação unificada por parte da Confederação e/ou Federação.

Os países que têm o Governo como principal organizador do esporte de alto nível possuem leis, ações e sistema organizacional que estão vigentes há muitos anos, como é o caso da China, que possui seu programa esportivo desde 1950, e, mesmo com trocas de governantes, o programa ainda mantém as mesmas bases ${ }^{8}$. Na Austrália, o Instituto Nacional de Esporte controla as federaçóes esportivas, e, no Reino Unido, existe integração entre projetos governamentais e entidades de cada modalidade para desenvolver o esporte de base, mediante diversos projetos ${ }^{13}$.

No Brasil, como visto anteriormente, duas organizaçóes em nível nacional são responsáveis especificamente pelo desenvolvimento do esporte de alto nível: o COB e o Ministério do Esporte, por meio da Secretaria Nacional de Alto Rendimento. Ambos, juntamente com o Conselho Nacional de Esporte, formam o Sistema Nacional de Esporte, que elabora as políticas de Esporte de alto rendimento.

No entanto, quando são analisados os programas e projetos desses dois órgãos, não são encontradas açôes de política para o esporte implantadas nacionalmente. Um exemplo disso é o programa Bolsaatleta, citado por apenas um dos técnicos (9\%), e que, em sua opinião, não apresenta critérios claros para sua distribuição. Na prática, não se observa a operacionalizaçáo de programas e projetos governamentais de forma integrada nos Estados brasileiros, assim como não se consegue identificar um plano estatal para o esporte no país ${ }^{34-35}$.

Portanto, a responsabilidade pela elaboração de diretrizes para o desenvolvimento da natação de alto rendimento no país é dos clubes e Entidades Municipais de Práticas Desportiva. Esses, por sua vez, não recebem nenhum tipo de diretriz da Confederação e Federação que representam a modalidade, como pode ser verificado no DSC1 referente à TABELA 3.

Já em países com sucesso na natação internacional, como EUA, Austrália e Reino Unido, as Confederaçóes são a base para o desenvolvimento de atletas de alto rendimento ${ }^{32,36-37}$. No Reino Unido, em 1999, a Amateur Swimming Association (ASA) criou um projeto nacional que funciona por meio de auditorias prestadas a todos os clubes associados, nas quais se identificam as áreas em que os clubes possuem deficiências, tais como: ensino, desenvolvimento de habilidades, desenvolvimento competitivo e performance; e a partir das falhas detectadas, a ASA presta assistência a esses clubes ${ }^{36}$. Na Austrália e nos EUA, existem programas nacionais voltados para clubes e técnicos, por meio de certificaçóes, cursos, congressos e encontros. Desse modo, são passadas diretrizes a serem implantadas nacionalmente, tanto em relação ao treinamento de crianças e jovens, como em relação aos nadadores de alto rendimento ${ }^{32,36-37}$.

Em relação às diretrizes estabelecidas pelas entidades que organizam a natação no Estado de São Paulo e no Brasil, as ações da CBDA e da FAP que foram identificadas, tanto nas respostas dos técnicos, quanto nas dos funcionários, foram em relação ao Conselho Técnico da CBDA e da FAP. O Conselho Nacional e o Estadual são formados por técnicos de clubes que se destacam na nataçáo regionalmente e nacionalmente. Esses Conselhos, de acordo com os técnicos e funcionários entrevistados, tomam decisóes relacionadas a regulamentos, calendários, índices de participação etc. No entanto, não existem decisões relacionadas ao desenvolvimento técnico e treinamento da modalidade, como ocorre em outros países com sucesso na natação mundial.

Portanto, foi verificado, em relação às diretrizes nacionais para o desenvolvimento da natação de alto rendimento, que o clube tem o papel principal, atuando com diretrizes próprias e sem suporte da FAP, CBDA, COB ou Ministério do Esporte. As funçóes das entidades organizadoras estão voltadas, prioritariamente às competiçóes, como elaboração de regulamentos, organização de calendários e de índices.

No contexto mundial, em algumas naçóes como China, Austrália e Alemanha, os Governos ou Instituiçôes Nacionais de Esporte subsidiam o esporte de elite em nível nacional, e, portanto, quem recebe essa verba deve prestar contas para a entidade que as subsidia. $\mathrm{O}$ aporte financeiro concedido a Confederaçóes, Federações, clubes, técnicos e atletas pode vir do Governo, do Governo em parceria com instituiçóes, de patrocinadores ou empresas 
privadas, sendo esse ponto diretamente influenciado pela administração do esporte em cada país ${ }^{7,21}$.

Assim, verificou-se que grande parte das entidades de prática desportiva pesquisada (90\%) presta contas somente à própria entidade, sejam os clubes, sejam as Entidades Municipais de Práticas Desportiva. De acordo com os técnicos dos clubes, a prestação de contas ocorre diretamente à diretoria, aos associados e aos atletas. Em relaçáo às Entidades Municipais de Práticas Desportivas, a prestação de contas ocorre por meio do Departamento de Esportes ou diretamente à Prefeitura (TABELA 4).

$\mathrm{Na}$ China e na Rússia, os fundos financeiros provenientes do Governo são destinados, principalmente, ao esporte de base, ao passo que investimentos de patrocinadores internacionais são destinados ao esporte de alto rendimento. Já na França, todo o investimento no esporte é realizado pelo Governo, principalmente por meio do dinheiro obtido pela loteria. Alemanha, Austrália, Reino Unido e Itália são países que possuem o Governo como principal agente de suporte financeiro, e, por meio de Ministérios, Institutos Nacionais e Federaçóes Esportivas repassam o dinheiro para diferentes categorias do esporte nacional, no entanto, são países abertos ao sistema de patrocinadores. Estados Unidos e Japão são considerados países totalmente abertos às empresas privadas e patrocinadoras do esporte nacional ${ }^{3}$.

$\mathrm{O} \mathrm{COB}$, para desenvolver o esporte nacionalmente, recebe do Ministério do Esporte o repasse de $85 \%$ dos $2 \%$ da arrecadação bruta de todas as loterias federais do país, tal como estipulado pela Lei Agnelo-Piva (n. 10.264), sancionada em julho de 2001, com a finalidade de desenvolver os esportes olímpicos no país. Para receber os recursos financeiros provenientes do $\mathrm{COB}$, as Confederaçóes Esportivas devem atender a determinados critérios. Um requisito básico é a apresentação de um planejamento das atividades da Confederaçáo para a aplicação desses recursos financeiros ${ }^{25}$.

De acordo com os técnicos entrevistados, no Estado de Sáo Paulo os clubes e as Entidades Municipais de Prática Desportiva não recebem suporte algum, inclusive financeiro, de nenhuma entidade nacional e/ou governamental ligada ao esporte de alto rendimento. Cada um destes arca com suas despesas, não sendo necessária, portanto, a prestaçáo de contas a nenhum outro órgão, como exemplificado por meio do DSC3, referente à TABELA 4.

Em virtude da autonomia dada aos clubes e às Entidades Municipais de Práticas Desportivas por parte da CBDA e da FAP, cada clube é livre para desenvolver o trabalho de acordo com suas próprias diretrizes de treinamento e desenvolvimento de atletas, como descrito anteriormente. Esse pode ser considerado um problema na estrutura organizacional da natação de alto rendimento no Estado de São Paulo, assim como no Brasil.

Em países como Austrália, China, Alemanha, França, Reino Unido, Itália, Rússia e EUA, existem programas nacionais voltados para o desenvolvimento do esporte de alto rendimento. Esses programas são elaborados de acordo com a realidade de cada país e possuem bases estruturadas de funcionamento. Entre os fatores que sustentam esses programas está o controle do treinamento centralizado, que é considerado determinante para o sucesso esportivo internacional de um país ${ }^{21}$.

Dois técnicos (18\%) afirmaram que suas entidades prestavam contas a "Várias auditorias" e "Para patrocinadores". No entanto, esses fatos são isolados, resultantes da estrutura organizacional dessas entidades de prática desportiva. Segundo os funcionários da FAP, a prestação de contas só ocorre para os clubes filiados.

De modo geral, verificou-se que a administração das açóes e políticas esportivas para o desenvolvimento da natação no Estado de São Paulo não acontece de modo centralizado, por meio de entidades nacionais como o $\mathrm{COB}$ ou o Ministério do Esporte, ou por qualquer entidade organizadora da modalidade, como CBDA ou FAP.

Verificou-se que os órgãos nacionais como $\mathrm{COB}$, Ministério do Esporte e Confederação Brasileira de Desportos Aquáticos (CBDA), possuem como principais funções: auxiliar os atletas da Seleção Brasileira; conceder a Bolsa-atleta; auxilio a atletas da Seleção Brasileira e organização de eventos/competiçôes em nível nacional. Já em nível Estadual, os entrevistados afirmaram que a Federação Aquática Paulista (FAP) organiza eventos/competições, e os clubes e as Entidades Municipais de Práticas Desportivas são responsáveis pela formaçáo esportiva de base e para o alto rendimento.

A comunicação entre os clubes e as Entidades Municipais de Práticas Desportivas com a FAP ocorre de maneira limitada aos aspectos burocráticos e na participação em eventos e competições organizados pela Federação. A CBDA se comunica diretamente com os atletas somente para distribuição de patrocínio, e os atletas diretamente com o Ministério do Esporte para a obtenção da Bolsa-atleta.

De maneira geral, o que pode ser observado é que a administração de açôes e políticas esportivas 
para o desenvolvimento da natação de alto rendimento (na definição de diretrizes, aplicação de recursos financeiros, prestação de contas, auditorias e relacionamento com patrocinadores) ocorre por meio dos Clubes e Entidades Municipais de Prática Desportiva, de maneira isolada?

Constatou-se, ainda, que o Ministério, COB e CBDA não participam da elaboração de diretrizes e planos de açóes nacionais voltados para o desenvolvimento da natação de Alto Rendimento no Estado de São Paulo. Essa função é exercida pelos Clubes e Entidades Municipais de Prática Desportiva, e acredita-se que deve ocorrer também em outros Estados, assim como em outras modalidades.

Dessa forma, existem pontos na estrutura e organização da natação no Estado de São Paulo que devem ser melhor desenvolvidos. Para isso, sugere-se a aplicação de procedimentos já consagrados na realidade de outros países nos quais esses fatores são bem desenvolvidos, adaptando-se ao contexto da realidade de São Paulo e do Brasil. De acordo com a literatura internacional, existe uma tendência de homogeneidade nos sistemas esportivos de diferentes países ${ }^{7-8}$. Países que possuem sucesso esportivo internacional adotaram ideologias em termos organizacionais do esporte de países do antigo bloco oriental, como Rússia e a antiga Alemanha Oriental. Outro exemplo é a China, que adotou estratégias de gestáo do basquete da Liga Norte-Americana de Basquete (NBA) e conseguiu desenvolver a modalidade no país alcançando resultados internacionais expressivos, provando assim que é possível, com as devidas adaptaçôes, adotar estratégias de países com sucesso esportivo para a nossa realidade ${ }^{38}$.

Com relação aos resultados de outras pesquisas comparativas internacionais sobre o tema estudado, pode-se concluir, ainda, que o esporte brasileiro necessita de estruturaçáo esportiva nacionalmente, para que programas e projetos esportivos funcionem de maneira regional, mas, de modo integrado com diretrizes propostas e coordenadas por órgãos governamentais e entidades nacionais do esporte.

Além disso, conclui-se que as entidades de administração do esporte ligadas à natação no Estado de São Paulo e no Brasil não elaboram material institucional consistente, não existe ampla divulgação das atividades desenvolvidas, assim como as açôes administrativas e políticas para a área esportiva não tem sido objeto de pesquisa científica pela academia.

A investigação da estrutura organizacional da natação no Estado de São Paulo foi um trabalho inovador na área, pois além de retratar a realidade da estrutura de uma modalidade específica no Estado de São Paulo, verificou a adequação do instrumento de pesquisa. Este trabalho poderia ser aplicado para outras modalidades e em diferentes níveis organizacionais, tanto para contribuir com o conhecimento teórico sobre o assunto, quanto como ponto inicial para a proposição de intervençóes práticas.

Sugere-se a realizaçáo de mais estudos desta nature$\mathrm{za}$, com maior profundidade e por meio de outros instrumentos de pesquisa, como por exemplo, entrevistas e aplicação de questionários objetivos, específicos para cada modalidade ou grupo de modalidades esportivas. Trabalhos científicos desta natureza poderão contribuir para traçar cenários mais realistas, com o objetivo de fundamentar açóes mais efetivas para o desenvolvimento do esporte de rendimento no país.

Como é de conhecimento público, o Brasil sediou em 2014 a Copa do Mundo de Futebol, e sediará em breve outro evento esportivo de relevância mundial, os Jogos Olímpicos em 2016. Portanto, trabalhos que visem a investigar e entender a estrutura esportiva serão de grande importância e relevância, pois apontarão como os pontos fundamentais da estruturação esportiva estáo sendo desenvolvidos, apontando possíveis mudanças, intervençóes e adequaçóes necessárias. Dessa forma, o conhecimento científico poderá ser um dos legados dos megaeventos para o desenvolvimento do esporte no país.

\section{Abstract}

\section{Analysis of sport organization and structure of swimming in São Paulo State}

The aim of this research is to analyze the organizational structure for high level swimming in the State of Sao Paulo. To achieve this goal a semi-structured interview was performed with eleven elite swimming coaches of the State of São Paulo, and two officials of the Paulista Aquatic Federation. The results were analyzed through Group Character Speech Method (GCS). It was verified that the clubs and Municipal Entities of Sports Practices are responsible for sports training for grassroots and elite athletes. 
The action's and policies administration for the development of high level swimming in the State of São Paulo does not happen in a centralized way through national organizations such as the COB or the Ministry of Sports, as well as any specific organization, such as FAP or CBDA. The actions and policies management for the development of elite athletes in swimming are responsibility of clubs and Municipal Sports Practices Entities on an individual form, like the definition of guidelines, application of financial resources, accountability, audits and relationships with sponsors.

KEY WoRDS: Sport structure; Swimming; Elite sport development.

\section{Referências}

1. Meira TB, Bastos FC, Böhme MTS. Análise da estrutura organizacional do esporte de rendimento no Brasil: um estudo preliminar. Rev Bras Educ Fís Esporte. 2012;26:251-62.

2. Digel $\mathrm{H}$. The context of talent identification and promotion: a comparison of nations. New Stud Athl. 2002;17:13-26.

3. Meira TB, Bastos FC. Estrutura organizacional esportiva. In: Böhme MTS, organizadora. Esporte infanto juvenil: treinamento a longo prazo - talento esportivo. São Paulo: Phorte; 2011.

4. De Bosscher V, Bingham J, Shibli S, Van Bottenburg M, De Knop. The global sporting arms race: an international comparative study on sports policy factors leading to international sporting success. Oxford: Meyer \& Meyer Sport; 2008.

5. De Bosscher V, De Knop P, Van Bottenbrug M, Shibli S, Bingham J. Explaining international sporting success: an international comparison of elite sport systems and policies in six countries. Sport Manag Rev. 2009;12:113-36.

6. De Bosscher V, Shibli S, Van Bottenbrug M, De Knop P, Truyens J. Developing a method for comparing the elite sport systems and policies of nations: a mixed research methods approach. J Sport Manag. 2010;24:567-600.

7. Green M, Oakley B. Elite sport development systems and playing to win: uniformity and diversity in international approaches. Leis Stud 2001;20:247-67.

8. Houlihan B, Green M. Comparative elite sport development: systems, structures and public policy. Burlington: Elsevier; 2008.

9. Thumm H. Talent identification in Indonesia: a model for other countries? New Stud Athl. 2006;21:29-39.

10. Ziemainz H, Gulbin J. Talent selection, identification and development exemplified in the Australian Talent Search Programme. New Stud Athl. 2002;17:27-32.

11. Meira TB, Mazzei L, Bastos FC, Böhme MTS. Programas de desenvolvimento de talentos esportivos nas pesquisas comparativas internacionais sobre esporte de alto rendimento e na realidade brasileira. Rev Min Educ Fís. 2012;20:37-73.

12. De Bosscher V, De Knop P, Van Bottenburg M, Shibli S. A conceptual framework for analysing sports policy factors leading to international sporting success. Eur Sport Manag Q. 2006;6:185-215.

13. Green M. Changing policy priorities for sport in England: the emergence of elite sport development as a key policy concern. Leis Stud. 2004;23:365-85.

14. COB. Comitê Olímpico Brasileiro. O Brasil nos jogos. Rio de Janeiro: COB; 2013. [citado 16 jul. 2013]. Disponível em: http://timebrasil.cob.org.br/brasil-nos-jogos.

15. FINA. Federation Internationale de Natation. Events. Lausanne: FINA; 2011. [cited 2011 mai 6]. Available from: http://www.fina.org/H2O/index.php?option=com_content\&view=article\&id=916\&Itemid=180.

16. CBDA. Confederação Brasileira de Desportos Aquáticos. Natação. Brasil: CBDA; 2011. [citado 6 mai. 2011]. Disponível em: http://www.cbda.org.br/esporte/natacao.

17. Ferreira RM. O contexto do desenvolvimento de nadadores medalhistas olímpicos brasileiros [dissertação]. Belo Horizonte (MG): Universidade Federal de Minas Gerais, Escola de Educação Física, Fisioterapia e Terapia Ocupacional; 2010.

18. Thomas J, Nelson J. Métodos em pesquisa em atividade física. 3a ed. Porto Alegre: Artmed; 2002.

19. FAP. Federaçáo Aquática Paulista. Natação. Brasil: FAP; 2011. [citado 6 mai. 2011]. Disponível em: https://www. aquaticapaulista.org.br/natacao.php.

20. Lefèvre F, Lefèvre AMC. O discurso do sujeito coletivo: um novo enfoque em pesquisa qualitative. Caxias do Sul: EDUCS; 2003.

21. Digel H. A comparison of competitive sport systems. New Stud Athl. 2002;17:37-50.

22. Röger U, Rütten A, Ziemainz H, Hill, R. Quality of talent development systems: results from an international study. Eur J Sport Soc. 2010;7:7-19. 
23. Rütten A, Ziemainz H, Röger U. Qualitätsgesichertes system der talentsuche und auswahl: Theoretischer Ansatz, Methode erste Ergebnisse. In: Emrich E, Güllich A, Büch MP. Beiträge zum Nachwuchsleistungssport. Schorndorf: Hofmann Verlag; 2005.

24. Brasil. Lei n. 9.615, de 24 de março de 1998. Institui normas gerais sobre desporto e dá outras providências. Diário Oficial da União, Brasília (25 mar. 1998):Seção 1:1. [citado 16 jul. 2013]. Disponível em: http://www.senado.gov.br.

25. Brasil. Lei n. 10.264, de 16 de julho de 2001. Acrescenta inciso e parágrafos ao art. 56 da Lei no 9.615 , de 24 de março de 1998, que institui normas gerais sobre desporto, 2001. Diário Oficial da União, Brasília (17 jul 2001):Seção 1:1. [citado 16 jul. 2013]. Disponível em: http://www.planalto.gov.br/ccivil_03/Leis/LEIS_2001/L10264.htm.

26. CBC. Confederação Brasileira de Clubes. Legislação esportiva. Campinas: CBC; 2013 . [citado 16 jul. 2013]. Disponível em: http://www.cbc-clubes.com.br/site/institucional/consultoria.php.

27. Brasil. Tribunal de Contas da União. Relatório de auditoria: esporte de alto rendimento. Brasília: Secretaria de Fiscalização e Avaliação de Programas de Governo; 2010. [citado 6 mai. 2011]. Disponível em: http://portal2.tcu.gov.br.

28. São Paulo (Estado). Secretaria de Esporte, Lazer e Juventude. Conjuntos desportivos. São Paulo: Governo do Estado de São Paulo; 2011. [citado 6 mai. 2011]. Disponível em: http://www.saopaulo.sp.gov.br/.

29. São Paulo (Município). Secretaria Municipal de Esportes, Lazer e Recreação. Equipamentos. São Paulo: Prefeitura de São Paulo; 2011. [citado 6 mai. 2011]. Disponível em: http://www.prefeitura.sp.gov.br/cidade/secretarias/esportes/.

30. Almeida GO. O processo de identificação e desenvolvimento de talento nas grandes potências esportivas [monografia]. São Paulo (SP): Universidade de São Paulo, Escola de Educação Física e Esporte; 2006.

31. COB. Comitê Olímpico Brasileiro. Demonstração da aplicação dos recursos provenientes da Lei Agnelo-Piva 2009. Rio de Janeiro: COB; 2012. [citado 12 ago. 2012]. Disponível em: http://www.cob.org.br.

32. Green M, Houlihan B. Elite sport development: policy learning and political priorities. New York: Routledge; 2005.

33. Brasil. Ministério do Esporte. Bolsa atleta: inscrições. Brasília: Ministério do Esporte, 2012. [citado 12 ago. 2012]. Disponível em: http://www.esporte.gov.br/snear/bolsaAtleta/default.jsp.

34. Azevedo PH, Barros JF. O nível de participação do Estado na gestão do esporte brasileiro como fator de inclusão social de pessoas portadoras de deficiência. Rev Bras Ciênc Mov. 2004;12:77-84.

35. Zouain DM, Alves JAB, Pieranti OP. Relatório final de atividades do Fórum de Discussão Permanente de Políticas de Esporte. Rev Admin Públ. 2006;40:731-8.

36. Collins MF. Examining sports development. New York: Routledge; 2010.

37. USA Swimming [homepage]. Colorado Springs: USA Swimming National; 2011. [citado 6 mai. 2011]. Available from: http://www.usaswimming.org.

38. Houlihan B, Tan T, Green M. Policy transfer and learning from the West: elite basketball development in the people's Republic of China. J Sport Soc Issues. 2010;34:4-28.

ENDEREÇO

Tatiana de Barros Meira Escola de Educação Física e Esporte - USP

Av. Prof. Mello Moraes, 65

05508-030 - São Paulo - SP - BRASIL e-mail: tati_meira7@hotmail.com
Recebido para publicação: 24/07/2013

1a. Revisão: 10/04/2014

2a. Revisão: 14/07/2014

3a. Revisão: 15/12/2014

4a. Revisão: 16/03/2015

Aceito: 14/04/2015

600 • Rev Bras Educ Fís Esporte, (São Paulo) 2015 Out-Dez; 29(4):583-60o 